\title{
Effect of Leaf Extract (Jatropha curcas L.) Towards the Microbiolagic Quality of Layang Fish TPC (Decapterus sp.) At Room Temperature Storage
}

\author{
${ }^{1}$ Rahim Husain, ${ }^{2}$ Lis M Yapanto, ${ }^{1}$ Zenab Y. Umar \\ ${ }^{1}$ Department of Fisheries Product Technology, Faculty of Fisheries and Marine Sciences, Gorontalo State \\ University, Jl. General Sudirman No. 06, Gorontalo City 96128, Gorontalo, Indonesia
}

${ }^{2}$ Department of Aquatic Resources Management, Faculty of Fisheries and Marine Sciences, Gorontalo State University, Jl. General Sudirman No. 06, Gorontalo City 96128, Gorontalo, Indonesia

${ }^{2}$ Corresponden author: lizrossler@ung.ac.id

Article History: Received:11 January 2021; Accepted: 27 February 2021; Published online: 5 April 2021

\begin{abstract}
This study aims to determine the effect of Jatropha Curcas L. leaf extract on the freshness quality of Layang Fish (Decapterus sp.) At room temperature storage. The research consisted of two stages, namely preliminary research and main research. Preliminary research is determining the concentration of castor leaves. The main research is the concentration of Jatropha leaves used, which is $16 \%$ with a storage time of 10 hours, 14 hours, 18 hours and 22 hours. The test was carried out organoleptically (hedonic quality) and TPC. This design uses kruskall wallis for organoleptic data (hedonic quality), CRD to obtain TPC results. Organoleptic data and TPC that had a significant effect were tested by Duncan's continued test. The results showed that the fresh fly fish preserved with $16 \%$ castor leaf extract was able to maintain the quality of the fresh fly fish for 14 hours of storage. The chemical test results showed that the fresh fly fish with $16 \%$ castor leaf extract in 14 hours of storage, the microbiological quality obtained ALT value of 5.03 CFU / g, this fulfills SNI 2729.2013 concerning fresh fish.

Key words: Jatropha curcas L. leaf, Layang Fish (Decapterus sp.), Storage, hedonic quality and TPC.
\end{abstract}

\section{Preliminary}

Fish is a high source of animal protein. In fish meat there are compounds that are needed by the body, where chemically fish meat contains $75 \%$ oxygen, $10 \%$ hydrogen, $9.5 \%$ carbon and $2.5 \%$ nitrogen. These elements consist of protein, fat, carbohydrates, vitamins and mineral salts.

One type of fish resource that has a high production of 3,601,190 tons / year is flying fish (Decapterus sp.). Flying fish in Indonesia, especially Gorontalo, are very abundant. The potential for flying fish in 2014 is 1,941.5 tons (Berita Satu, 2015) so that the selling price of flying fish is relatively cheap, especially for small flying fish. Flying fish begin to experience a decline in physical quality after death, this damage can occur biochemically and microbiologically, this is caused by several things such as environmental conditions which are very suitable for the growth of rotting microbes caused by bacteria, yeast, and fungi.

The deterioration of the quality of foodstuffs is a major problem faced in the handling of foodstuffs, especially fresh food, due to high water content. The deterioration of food quality is caused by enzymatic activities in the fish body and the growth of microorganisms. Microbes can come from the fish's body itself or from postharvest handling that does not meet the requirements. Food that has been damaged means that it has decreased in quality so that it is not suitable for consumption, although its appearance is still in accordance with the quality criteria (Widyasari, 2006).

The process of preserving fish is an important part of the chain of fisheries industry, where preservation aims to maintain the freshness of the fish as long as possible by inhibiting the causes of deterioration of quality. To maintain the quality of freshness, it can be handled using ice and natural preservatives to maintain the freshness of the fish. Exploration of natural preservatives which have the potential as food preservatives is needed nowadays, to reduce the use of synthetic chemicals such as jatropha.

Jatropha is included in the Euphorbiaceae family, the genus Jatropha has leaves that are efficacious as a medicine for itching, flatulence, eczema, and fungi between the legs. Jatropha leaves contain phenols, terpenoids, flavonoids, saponins (Oskoueian et al., 2011), and alkaloids (Gupta et al., 2011). In Sisunandar's research, he said that there was antibacterial activity in the Chinese castor leaf extract (Sisunandar, 2002). The results of this study showed that the Chinese castor leaf extract was able to inhibit the growth of Staphylococcus aureus bacteria with an inhibitory concentration of at least $8 \%$ and Escherichia coli bacteria with a concentration of 5\%. Jatropha leaves and jatropha leaves contain the same chemical compounds, namely flavonoids, saponins and tannins which can inhibit bacterial growth (Sisunandar, 2002).

To determine the effect of jatropha leaf extract (Jatropha curcas L) on the freshness quality of flying fish (Decapterus sp.) At room temperature storage. 


\section{Research methods}

The research was conducted from March to August 2020, oranganoleptic testing took place at the Laboratory of the Department of Fisheries Products Technology, Faculty of Fisheries and Marine Sciences, Gorontalo State University and microbiological and chemical testing was carried out at the Agricultural Product Technology Laboratory, Gorontalo Polytechnic.

\section{Tools and Materials}

The tools used in this research include a coolbox, a sample storage container, plastic packaging, an organoleptic testing table, a sink, a container / pan, a camera, a fresh fish score sheet (SNI-01-2346-2006), elenmeyer, beaker glas, hot plate, magnetic stirrer, autoclave, label paper, bunsen, analytic scales, sterile plastic, scissors, tweezers, blender, test tube rack, petridish, colonycounter, alumenium plate, desiccator, incubator, $35 \pm$ $10 \mathrm{C}$, oven, waterbath, pipette, thermometer digital, film bottles, organoleptic score sheets, and digital scales. The tools for TPC analysis are erlenmeyer flask, pipette, petri dish, test tube, incubator, bunsen, beaker, and bacteria counting device. (PCA) media.

Materials to be used include fresh flying fish, jatropha leaves, distilled water, and Plate Count Agar

\section{Results and Discussion}

\subsection{Quality Characteristics Hedonic Fish (Decapterus sp.) Fresh}

Organoleptic test of flying fish (Decapterus sp.) Which was conducted was a test of hedonic quality. Based on SNI 2729: 2013, organolpetic assessment of fresh fish includes quality specificationseyes, gills, mucus, flesh, smell and texture. The assessment was carried out by semi-trained panelists totaling 25 people.

\section{Eye}

Data from the analysis of the effect of storage time on the organolpetic quality of flying fish eye appearance can be seen in Figure 1. The histogram of the results of the flying fish quality test.

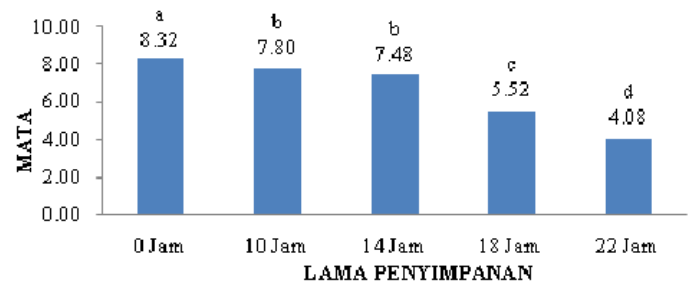

Figure 1.Histogram of quality test results hedonic appearance fish eye with long storage ones different.

Based on the results of the study showed that the longer the storage of the organoleptic value of the fish eye soaked using Jatropha leaf extract decreased. This is because after the fish dies, the immune system that keeps the fish from being attacked by bacteria does not work anymore and bacteria begin to enter the fish's body. The putrefactive bacteria in fish comes from outside the fish body which enters through the skin or from within the fish's body itself. Organoleptic changes in the eye of flying fish are caused by the growth of bacteria that change the cell membrane. This is in accordance with Agati, et al. (2007) in Herawati (2011) that the permeability of the cell membrane in fish eyes is disrupted due to the presence of phenol and tannin compounds in jatropha leaves, causing changes in the eye appearance of the fish.

Jatropha leaves contain phenols, terpenoids, flavonoids, saponins (Oskoueian et al., 2011), and alkaloids (Gupta et al., 2011). In Sisunandar's research, he said that there was antibacterial activity in the Chinese castor leaf extract (Sisunandar, 2002). The toxicity of phenol compounds to bacteria depends on the number of hydroxyl groups and the concentration given. Phenols bind to proteins through hydrogen bonds causing the protein structure to be damaged. Phenols are able to cause cell protein coagulation and lyse cells at high levels, while at low concentrations a phenol protein complex is formed with weak bonds and immediately decomposes so that the antibacterial effect is weak (Sari et al. 2010).

\section{Gill}

Data from the analysis of the effect of storage time on the organolpetic quality of the appearance of flying fish gills can be seen in Figure 2. The histogram of the results of the flying fish quality test. 


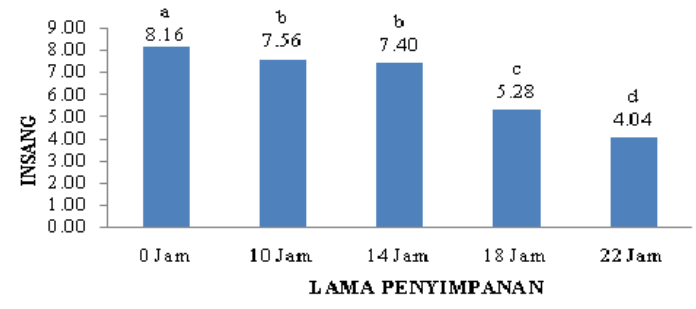

Figure 2. Histogram of quality test results hedonic appearance fish gills with long storage ones different.

$$
\text { different. Alphabet that same on the histogram shows the results are not real }
$$

Based on the results of the study showed that the longer the storage, the appearance of flying fish gills decreased the organoleptic value. The rapid loss of quality in the gills is inseparable from the performance of the gills which filter oxygen in the water during respiration so that the gills become a place for microbes to accumulate (Bakara, 2016). This situation can be explained through a diffusion reaction (equilibrium) which causes the leaf solution with a concentration of $16 \%$ during immersion will experience a change in concentration due to the entry of most of the solution into the body of the flying fish, then it will come out again at a certain hour and cause an equilibrium between the leaves of the jatropha solution. is outside the fish body and inside the fish body.

A decrease in the quality of the flying fish gills is indicated by a change in the color of the gills from brilliant red to brownish red, looks a bit slimy and has a more pronounced sour smell (Berhimpon, et al, 2002). The decline in the quality of the flying fish gills can also be caused by the mixing of the green pigment from the jatropha leaf extract on the gills, causing the red color of the flying fish's gills to fade. The results of this study showed that the Chinese castor leaf extract was able to inhibit the growth of Staphylococcus aureus bacteria with an inhibitory concentration of at least $8 \%$ and Escherichia coli bacteria with a concentration of 5\%. Jatropha leaves and jatropha leaves contain the same chemical compounds, namely flavonoids, saponins and tannins which can inhibit bacterial growth (Sisunandar, 2002).

\section{Mucus}

Data from the analysis of the effect of storage time on the organolpetic quality of the appearance of flying fish mucus can be seen in Figure 3. The histogram of the results of the flying fish quality test.

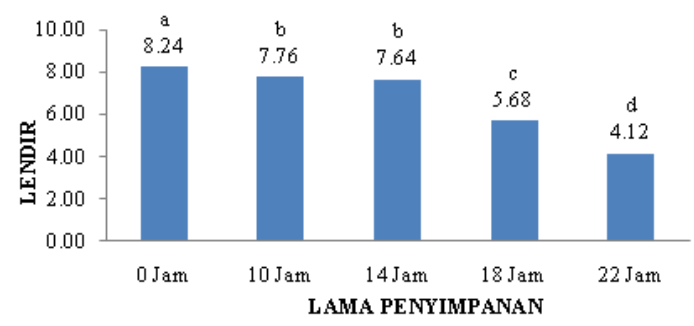

Figure 3.The histogram of the hedonic quality test results of the appearance of flying fish slime with different storage times. The same letter on the histogram shows results that are not significantly different.

Based on the results of the research that the longer the storage of the hedonic quality value, the appearance of flying fish mucus decreases, this is related to the presence of bacterial activity due to the activity of bacteria that utilize fish mucus for activities. Based on DKP (2008), many microbes are found on the outer surface of the fish body (skin and gills) and the intestines of fresh fish. According to Djojosentono (1982), one of the changes after the fish dies is that mucus is released from the glands in the skin, forming a thick clear layer around the fish's body. The mucus consists of gluco protein and becomes a good substrate for bacterial growth. So it is necessary to have jatropha leaves as antibacterial, but the longer the antibacterial storage on jatropha leaves is no longer effective.

Muniarti and Sunarman, (2000) naturally, the deterioration of fish freshness will be marked by a layer of mucus that starts to become cloudy on the surface of the fish. The thin thickness of the mucus or the cloudiness of the mucus layer is influenced by the activity of bacteria on the skin surface. In the process of spoilage of fish, there is a hyperaemia stage, namely fish mucus is released from its glands in the skin, forming a thick clear layer around the fish's body. In addition, if the ambient temperature rises, the activity of bacteria becomes faster, making the mucus release from the glands thick and cloudy.

\section{Meat}

Data from the analysis of the effect of storage time on the organolpetic quality of the appearance of flying fish meat can be seen in Figure 4. The histogram of the results of the flying fish quality test. 


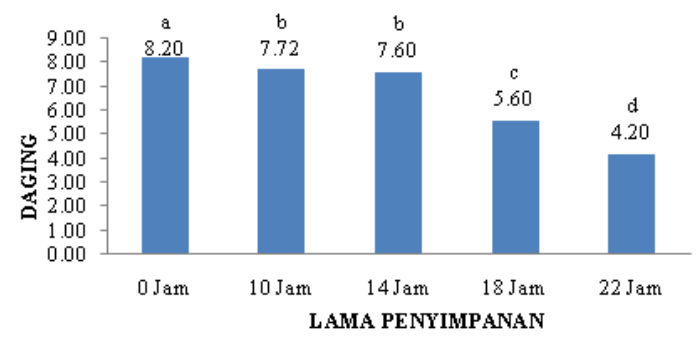

Figure 4.The histogram of the hedonic quality test results of the appearance of flying fish meat with different storage times. The same letter on the histogram shows results that are not significantly different.

Based on the research results, the detected organoleptic quality value of flying fish meat could be caused by the longer storage treatment, causing the rotting microorganisms in flying fish to be higher and growing, causing the meat quality to decline. The decline in quality is characterized by less strong or soft meat tissue. This indicates that the flying fish have entered the post rigor phase. This is in accordance with the opinion of Nurjanah et al., (2004) that the characteristics of post rigor, namely the texture of fish meat begin to soften. The decrease in the value of meat is also due to the presence of the catepinsin enzyme in fish meat which has a role in the process of decreasing the freshness of fish meat quality (Ladrat et al., 2003) in (Bakkara, 2016).

The decline in the quality of flying fish meat is also related to the presence of bacterial activity. So it is necessary to have antibacterial castor leaves. The use of jatropha leaf extract solution is a good alternative, because the active compounds contained therein, such as flavonoids, tannins, essential oils, alkaloids, these active substances have the ability to be antimicrobial. This is in accordance with the opinion of Octovrisna et al. (2013) that the ability of a microorganism is very dependent on the solution of the concentration of the microbial material, in addition to the concentration factor and the type of anti-microbial material. Furthermore, if the smaller the concentration dose, the less the number of active substances contained therein

\section{Smell}

Data from the analysis of the effect of storage time on the organolpetic quality of flying fish odor appearance can be seen in Figure 5. The histogram of the results of the flying fish quality test.

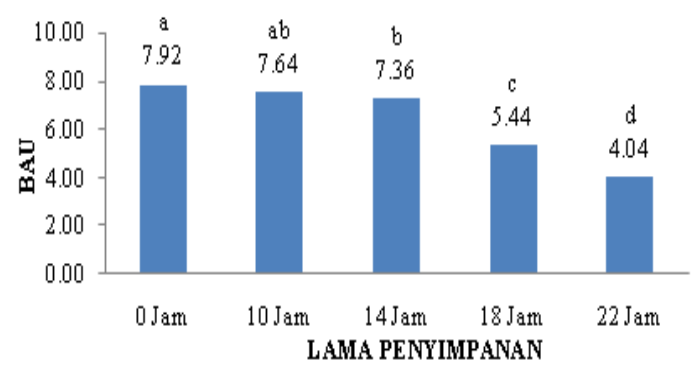

Figure 5.The histogram of the hedonic quality test results, the smell appearance of flying fish with different storage times. The same letter on the histogram shows results that are not significantly different.

Based on the research results that during the storage period, the distinctive smell of fresh fish for flying fish has decreased in quality which causes the organoleptic value of the odor to also decrease. This fishy (ammonia) odor arises from fish, which is a by-product of protein breakdown by bacterial activity. The smell of ammonia gradually leads to a bad smell. Fish rot is caused by microbial activity that causes fish damage. This decay occurs due to the process of breaking down proteins into simple molecules such as amino acids so that the cells in the fish body become damaged and rot.

The use of castor leaves as a preservative can affect the smell of flying fish. Jatropha leaves are thought to prevent the formation of side compounds resulting from protein denaturation that cause fish odor. The use of castor leaves can disguise the smell of fish so that the distinctive odor cannot be detected properly by the human senses but all that is smelled is the smell of castor leaves.

In addition, the smell quality of flying fish is also related to the high and low number of TPC colonies during storage. Based on the results of the TPC test on flying fish during storage showed that the number of colonies began to increase from 0 hours to 22 hours of storage. Although jatropha leaves contain substances such as flavonoids and triterpenes which act as antibacterials, this solution has a strong effect on fish. The fish will continue to experience deterioration in quality after the antimicrobial in the Jatropha leaf solution cannot maintain the quality of the fish. This can be caused by the compound components in the jatropha leaf solution that enter the tissue of the fish meat causing a diffusion reaction, namely the transfer of substances from the high concentration to the low concentration part. the difference in concentration in the two parts is called the concentration gradient. 
This is one of the factors causing the decreasing effectiveness of the Jatropha leaf solution, so that the renovation process that occurs in fish by microorganisms continues and causes a foul odor to appear in flying fish.

\section{Texture}

Data from the analysis of the effect of storage time on the organolpetic quality of the appearance of the flying fish texture can be seen in Figure 6. The histogram of the results of the flying fish quality test.

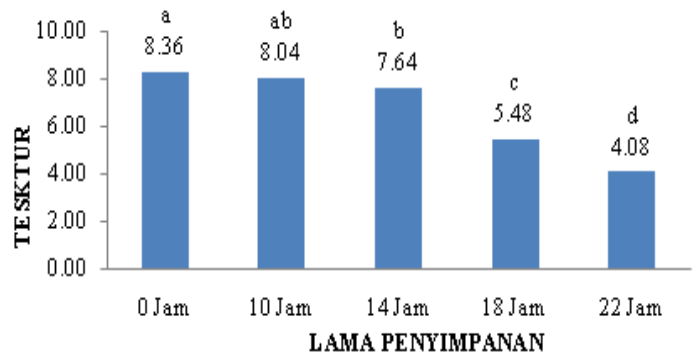

Figure 6.The histogram of the hedonic quality test results of the texture appearance of the flying fish with different storage times. The same letter on the histogram shows results that are not significantly different.

Based on the research results, the low organolpetic quality value of flying fish texture was caused by the longer storage time. This decrease is a result of the process of breaking down proteins by bacteria, resulting in the release of mucus which causes the texture of the fish to become soft. This is due to the autolysis process that causes changes in fish meat, for example, the texture of the meat becomes soft and easily detaches from the bones (Suptijah et al., 2008). According to (Poernomo et al., 1984 in Dwentro, GR 2017) that changes that occur in fish texture are caused by chemical changes such as the occurrence of aktimiocin as a result of the integration of actin and myosin proteins which can contribute to a large change in the hardness properties of fish meat.

The deterioration of texture quality along with the length of storage is caused by the higher number of microorganisms in yellow fly fish. This situation occurs because the antimicrobial compounds in the jatropha leaf extract are not effective in maintaining fish quality. Another factor that causes microbes to continue to grow is $\mathrm{pH}$. According to Juniato (2003) that at the rigormortis stage of the fish, microbes will begin to develop and remodel the texture of the fish meat so that the $\mathrm{pH}$ becomes unstable, this can be called the autolysis process. Autolysis is a process of changing the substance of the fish body by enzymes such as ATP-ase, which breaks down ATP into adenosine diphosphate, adenosine monophosphate, inosine monophosphate, inosine and hypokasatin (Quang, 2005). Other than that, The texture quality of flying fish is also related to the high and low number of TPC colonies detected during storage. The storage treatment of flying fish at a concentration of $16 \%$ for 22 hours of storage caused the number of TPC colonies to be higher, this could be caused by the antimicrobials contained in the Jatropha leaf solution unable to stop the growth of rotting microbes.

\subsection{Plate Number Analysis Test for Total Flying Fish (Decapterus sp)}

Data The results of the analysis of the effect of storage time on the TPC levels of flying fish can be seen in Figure 7. The histogram of fish ALT test results

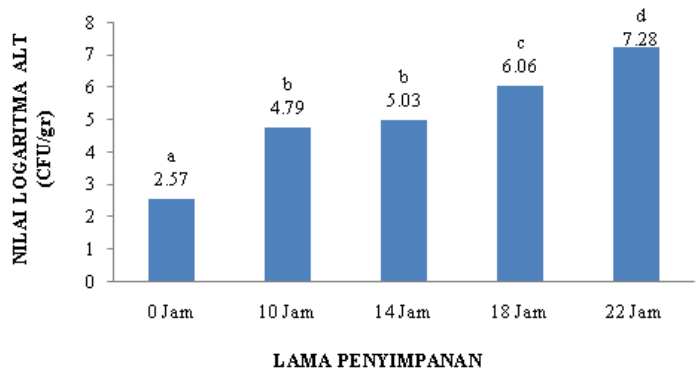

Figure 7.Histogram of fish ALT value test results letter on histogram show results that hover with long storage that not real different.

According to BSN (2013) the number of ALT bacteria in fresh fish is $5 \times 105$ colony / $\mathrm{g}$ (converted in the form of a logarithmic value to 5,699 CFU / g). Based on these limits, the results of the treatment of storage time with a concentration of $16 \%$ distance leaves can maintain the microbiological quality of the fish up to 14 hours compared to 18 hours and 22 hours of treatment. Based on these results, the leaf concentration of $16 \%$ was able to suppress bacterial growth during 14 hours of storage, because during the storage period the amount of TPC still met the standards based on SNI: 01-2729.1-2-2013 concerning the quality of fresh fish quality requirements. This is caused by antimicrobial compounds such as flavonoids in jatropha leaves which can inhibit microbial growth. 
However, along with the length of storage, the deterioration of the quality of the fish continues, so that the concentration of the Jatropha leaf solution can no longer maintain the freshness of the fish and causes rotting microorganisms to continue to multiply. Fardiaz (1992) states that microorganisms have various enzymes that can break down components resulting in changes in food properties such as appearance, taste, smell and texture. The treatment of jatropha leaf extract solution can cause the quality of flying fish to be maintained for the required time.

Octovrisna et al, (2013) added that the ability of a microorganism depends on the concentration of the antimicrobial material used, besides that the type of antimicrobial material also determines the ability to inhibit bacterial growth. Furthermore, if the smaller the dose, the less the number of active substances contained in it, so the lower the ability to inhibit the growth of a bacterium.

IV. Conclusion

Based on the results of research on the use of castor leaf extract with a concentration of $16 \%$ on the quality of fresh fly fish, it shows that there is a significant effect on the characteristics of organoleptic quality (eyes, gills, mucus, meat, smell and texture), microbiology (TPC), and chemistry (pH). ) during storage 0 hours 10 hours, 14 hours, 18 hours and 22 hours. The use of castor leaf extract is $16 \%$ capablemaintain the quality of fresh fly fish for 14 hours storage.

The chemical test results showed that the fresh fly fish soaked with $16 \%$ distance leaves for 14 hours of storage had a $\mathrm{pH}$ of 6.05 and in terms of microbiological quality, the ALT value was $5.03 \mathrm{CFU} / \mathrm{g}$, this fulfilled SNI 2729.2013 regarding fresh fish.

\section{Bibliography}

7. Indonesian National Standardization Agency. 2013. Fresh Fish. SNI 2729-2013. Indonesian National Standardization Council. Jakarta.

8. Berhimpon, S. 1993. Fish Fisheries Microbiology. Part 1. Ecology and Microbial Growth and Growth. Food Biochemistry. Fishery Products Processing and Quality Development Laboratory. Faculty of Fisheries and Marine Science. Sam Ratulangi University. Manado.

9. Yapanto, L. M., \& Modjo, M. L. (2018). Assessing public awareness level on the preservation of coral reefs (The case study in Biak Numfor, Papua, Indonesia). Ecology, Environment and Conservation, 24 (4).

10. DKP. 2008. Quarantine Fish Diseases for Bacteria. Fish Quarantine Center.

11. Djojosentono, S. 1982. Fish Handling and Processing Techniques. Ministry of Education and Culture, Directorate of Vocational Secondary Education.

12. Gupta MS, Arif M, and Ahmed Z. 2011. Antimicrobial activity in leaf, seed extract and seed oil of Jatropha curcas L. Journal of Applied and Natural Science, 3 (1): 102-105

13. Herawati. N. 2011. Identification of the Mangrove Plant Bioactive Compounds Sonneratia alba. Journal. Department of Chemistry. Faculty of Mathematics and Natural Sciences. Muhamadya University of Malang. Poor. Vol. 12. No. 2.

14. Junianto. 2003. Fish Handling Techniques. Self-Help Spreader. Jakarta.

15. Murniyati, AS, Sunarman. 2000. Fish Cooling, Freezing and Preserving. Publisher Kanisius, Yogyakarta.

16. Nurjanah, I. Setyaningsi, Sukarno and M. Muldani. 2004. Quality deterioration of red tilapia (Orecromis sp.) During storage at room temperature. Fishery Product Technology Bulletin. Volume VII Number 1.

17. Octovrisna, JR. 2013. Effect of various concentrations of ginger solution and immersion time on the total number of microbes in milkfish. Essay. Semarang: UNIMUS.

18. Oskoueian E., Norhani, A. \& Wan, Z., 2011. Antioxidant, Anti-inflammatory and Anticancer Activies of Methanolic Extracts From Jatropha curcas Linn. Journal of Medicinal Plants Research. Malaysia.

19. . Sisunandar., Julianto, T., Yulia, D., 2002. Antibacterial Compounds in Chinese Distance in Processing. XXII National Seminar on Indonesian Medicinal Plants, Purwokerto.

20. Widyasari, HE 2006. Effect of Preservation Using Picung (Pangium edule) Seeds on Freshness and Safety of Fresh Mackerel Fish (Rastrelliger brachsyoma). Thesis. Faculty of Agriculture, Bogor Agricultural University. Bogor. Sciences, P.,

21. Yapanto, L. M., Tanipu, F., Paramata, A. R., \& Actors, E. (2020). The Effectiveness Of Fishery Cooperative Institutions. 17(25), 1329-1338. 